\title{
IDENTIFIKASI EKSPEKTASI INVESTOR MELALUI KEBIJAKAN STRUKTUR MODAL, PROFITABILITAS, UKURAN PERUSAHAAN DAN GCPI
}

\section{Sugeng Haryanto}

Program D-III Keuangan dan Perbankan, Universitas Merdeka Malang, Malang, Indonesia

\begin{tabular}{l} 
Info Artikel \\
\hline Sejarah Artikel: \\
Diterima Mei 2014 \\
Disetujui Juli 2014 \\
Dipublikasikan September 2014 \\
\hline Keywords: \\
capital struktur policy; \\
firm size, profitability; \\
corporate governance perception \\
index; \\
firm value
\end{tabular}

\begin{abstract}
Penelitian ini bertujuan untuk menganalisis pengaruh kausalitas antara kebijakan struktur modal, ukuran perusahaan, profitabilitas yang diukur dengan ROA dan perapan GCG yang diukur dengan Good Corporate Perception Index (GCPI) terhadap ekspektasi investor yang diukur dengan nilai perusahaan. Teknik sampling yang digunakan dalam penelitian ini adalah purposive sampling. Sampel dalam penelitian ini adalah perusahan yang go public dan masuk dalam Indonesia Most Trusted Companies. Periode penelitian selama tahun 2012 dan 2013, serta mempublikasikan laporan keuangan 2012-2013. Jumlah sampel sebanyak 48 perusahaan. Teknik analisis yang digunakan regresi linier berganda. Hasil penelitian menunjukkan bahwa kebijakan struktur modal dan ukuran perusahaan tidak berpengaruh, sedangkan profitabilitas dan GCPI berpengaruh terhadap ekspektasi investor. Secarasimultan variabel kebijakan struktur modal, ukuran peusahaan, profitabilitas dan GCPI berpengaruh terhadap ekspektasi investor.
\end{abstract}

IDENTIFYING THE INVESTORS' EXPECTATION THROUGH THE CAPITAL STRUCTURE POLICY, PROFITABILITY, FIRM SIZE AND GCPI

\begin{abstract}
Abstrak
The objective of the study was to analyze the causality influence among capital structure policy, firm size, profitability which was measured by ROA and the implementation of GCG which was measured by Good Corporate Perception Index (GCPI) toward the investors' expectations which was measured by the company value. It was a purposive sampling study. The samples of this study were go public companies listed on the Indonesia's Most Trusted Companies. The period of the study was in 2012 and 2013, and financial reports from 2012 to 2013. The total samples were 48 companies. The data were analyzed by multiple linear regressions. The result of the study showed that the capital structure policy and firm size did not give any influence, whereas the profitability and GCPI gave influence toward the investors' expectations. Furthermore; capital structure policy, firm size, profitability and GCPI variables influenced simultaneously toward investors' expectations.
\end{abstract}

JEL Classification: G, G1, G11

\footnotetext{
Alamat korespondensi :

Jl. Terusan Raya Dieng No. 57 Malang
}

E-mail: p3et@yahoo.com 


\section{PENDAHULUAN}

Tujuan perusahaan adalah meningkatkan kesejahteraan pemilik, dengan mengoptimalkan nilai perusahaan. Nilai perusahaan mencerminkankesejahteraan pemilik. Manager, sebagai wakil dari pemilik, bertanggung jawab untuk mengelola dalam rangka meningkatkan nilai perusahaan. Optimalisasi nilai perusahaan dapat dicapai melalui pelaksanaan fungsi manajemen keuangan, dimana satu keputusan keuangan yang diambil akan mempengaruhi keputusan keuangan lainnya dan berdampak pada nilai perusahaan. Manajemen keuangan menyangkut penyelesaian atas keputusan penting yang diambil perusahaan, antara lain keputusan investasi, keputusan pendanaan, dan kebijakan dividen

Manajemen perusahaan mempunyai tugas mengelola berbagai sumber daya (resources) yang dimiliki perusahaan secara efektif dan efisien untuk lebih meningkatkan kinerja operasi. Tujuan manajemen keuangan memaksimumkan nilai perusahaan, maka tujuan manajer keuangan adalah merencanakan untuk memperoleh dan menggunakan dana guna memaksimalkan nilai organisasi (Weston \& Copeland, 1999). Perusahaan yang prestasi kinerja keuangan baik yaitu memperoleh laba bersih yang besar dan mampu membayar dividen secara rutin sehingga memberi sinyal positif terhadap harga saham. Menurut Harjito dan Martono (2005) tujuan manajemen keuangan yaitu memaksimumkan nilai perusahaan yang diukur dari harga saham perusahaan.

Nilai perusahaan yang sering dikaitkan dengan saham, adalah persepsiinvestor terhadap perusahaan. Semakin tinggi harga saham maka semakin tinggi pula nilai perusahaan (Fakhrudin \& Sophian, 2001). Nilai perusahaan lazim diindikasikan dengan price earing ratio (PER), yang merupakan tingkat kepercayaan pasar atau investor pada prospek perusahaan ke depan (Soliha \& Taswan, 2002). PER merupakan salah satu indikator kepercayaan investor atau pasar terhadap suatu perusahaan serta indikator kepercayaan pasar terhadap prospek pertumbuhan perusahaan.

Bagi analis keuangan, PER merupakan aspekyangmenarik,karenaPERmerupakanrasio pengukuran yang paling komprehensif tentang prestasi perusahaan, karena rasio penilaian tersebut mencerminkan perpaduan antara pengaruh rasio risiko dan rasio pengembalian (Weston \& Copeland, 1997). PER dapat digunakan untuk : a) menentukan nilai pasar saham dan dalam perusahaan sejenis PER dapat membantu untuk mengidentifikasikan saham-saham yang under valued dan over valued; b) menentukan nilai pasar saham pada masa mendatang; c) menentukan capitalization rate dari suatu saham. PER juga merupakan cerminan dari keberanian investor untuk membayar setiap rupiah harga saham untuk setiap rupiah laba yang dihasilkan oleh saham perusahaan tersebut.

Bagi investor PER mempunyai makna yang sangat penting. Dengan menganalisis faktor-faktor yang mempengaruhi PER investor dapat menanamkan danya sehingga hasilnya akan lebih optimal. Semakin tinggi PER suatu perusahaan, semakin banyak investor yang akan menanamkan modalnya. Hal ini menunjukkan bahwaperusahaanyangmempunyaikesempatan investasi yang paling menarik akan memperoleh kapital harga yang wajar, yaitu harga yang mencerminkan investasi potensial. Tingginya minat investor untuk berinvesatasi di suatu perusahaan akan meningkatkan nilai perusahaan tersebut. Jensen (2001) menjelaskan bahwa untuk memaksimumkan nilai perusahaan dalam jangka panjang, manajer dituntut untuk membuat keputusan yang memperhitungkan kepentingan semua stakeholder, sehingga manajer akan dinilai kinerjanya berdasarkan kemampuannya mencapai tujuan atau mampu mengimplementasikan strategi untuk mencapai tujuan ini.

Salah satu keputusan penting yang harus diambil manajemen adalah menentukan sumber-sumber pendanaan bagi perusahaan, yang tercermin dari struktur modal perusahaan. 
Sugeng Haryanto / Identifikasi Ekspektasi Investor melalui Kebijakan Struktur Modal ...

Struktur modal merupakan masalah yang penting bagi perusahaan karena akan mempunyai dampak langsung terhadap posisi keuangan perusahaan yang selanjutnya akan mempengaruhi nilai perusahaan (Ridloah, 2010). Kebijakan struktur modal merupakan suatu trade off antara risiko dan tingkat pengembalian. Penambahan hutang perusahaan akan memperbesar risiko perusahaan tetapi sekaligus juga memperbesar tingkat pengembalian yang diharapkan. Struktur modal yang optimal adalah struktur modal yang mengoptimalkan keseimbangan antara risiko dan pengembalian, sehingga memaksimumkan harga saham (Indriani \& Widyarti, 2013).

Keterkaitan antara struktur modal dan nilai perusahaan masih banyak diperdebatkan, baik secara empiris maupun teoritis. Perdebatan ini muncul berawal dari perbedaan pandangan mengenai struktur modal yang optimal, dan relevansi hubungan struktur modal dengan nilai perusahaan. Proposisi Modigliani dan Miller (1963) tentang penggunaan utang akan meningkatkan nilai perusahaan, merupakan awal dari perdebatan tersebut. Pandangan ini berpijak bahwa faktor yang menentukan nilai perusahaan tersebut adalah penghematan pajak karena utang dapat mengurangi pembayaran pajak (tax deductable). Penghematan pajak akan diterima secara kontinue. Penghematan pajak inilah yang merupakan kelebihan nilai perusahaan yang menggunakan utang dibanding dengan perusahaan yang tanpa menggunakan utang.

Selain itu terdapat juga pandangan tentang pengaruh struktur modal terhadap nilai perusahaan, yaitu alignment effect dan entranchment (Jandik \& Makhija, 2005). Dalam analisis alignment effect bahwa struktur modal yang didanai dengan hutang dapat meningkatkan nilai perusahaan. Perusahaan yang menerbitkan hutang menunjukkan perusahaan tersebut memiliki komitmen untuk meningkatkan kinerjanya. Selain itu dengan penggunaan hutang dapat mengurangi perilaku oportunis manajer yang ingin menggunakan arus kas bebas untuk membiayai kegiatan investasi yang berlebihan (Jensen, 1986). Struktur modal akan mempengaruhi nilai pasar perusahaan dengan cara meminimumkan biaya modal rata-rata (average cost of capital). Struktur modal yang optimal yaitu struktur modal yang dapat meminimumkan biaya modal rata-rata dan memaksimumkan nilai perusahaan adalah struktur modal yang optimal.

Dalam analisis entranchment, perusahaan yang menerbitkan hutang akan memungkinkan manajer menggunakan dana tersebut untuk kepentingan pribadi manajer (Jandik \& Makhija, 2005). Kondisi ini tentunya akan membuat perusahaan terbebani dengan pembayaran beban bunga atau angsuran-angsuran hutangnya, tetapi tidak dapat memanfaatkan hutang tersebut untuk meningkatkan kinerja perusahaan, sehingga tidak berdampak pada nilai perusahaan.

Penelitian terkait dengan struktur modal terhadap nilai perusahaan menunjukkan yang berbeda. Penelitian yang dilakukan Bukit (2012), menunjukkan bahwa struktur modal tidak berpengaruh terhadap nilai perusahaan. Kesuma (2009) struktur modal tidak berpengaruh terhadap harga saham. Pengaruh struktur modal terhadap nilai perusahaan termediasi melalui profitbilitas perusahaan. Artini dan Puspaningsih (2011) struktur modal berpengaruh tidak langsung terhadap nilai perusahaan melalui kebijakan dividen. Sedangkan Meythi et al. (2012) menunjukkan bahwa struktur modal berpengaruh terhadap nilai perusahaan. Sugihen (2003) menemukan bukti bahwa struktur modal berpengaruh tidak langsung dan negatif terhadap nilai perusahaan.

Ukuran perusahaan menggambarkan besar kecilnya suatu perusahaan yang dapat dinilai dari total assets yang dimiliki, jumlah penjualan, rata-rata total penjualan dan rata-rata assets. Ukuran perusahaaan menunjukkan jumlah pengalaman dan kemampuan tumbuhnya suatu perusahaan yang mengindikasikan kemampuan dan tingkat risiko dalam mengelola investasi yang diberikan para stockholder untuk meningkatkan kemakmuran investor. Hal ini menunjukkan bahwa 
perusahaan besar lebih menjanjikan kinerja yang baik (Lin, 2006). Salah satu tolak ukur yang menunjukkan besar kecilnya perusahaan adalah ukuran aktiva dari perusahaan tersebut. Perusahaan yang memiliki total aktiva besar menunjukkan bahwa perusahaan tersebut telah mencapai tahap kedewasaan dimana dalam tahap ini ukuran perusahaan sudah positif dan dianggap memiliki prospek yang baik dalam jangka waktu yang relatif lama, selain itu juga mencerminkan bahwa perusahaan relatif lebih stabil dan lebih mampu menghasilkan laba dibanding perusahaan dengan total asset yang kecil (Pangemanan \& Mawikere, 2011).

Ukuran perusahaan akan menentukan kepercayaaninvestor. Semakin besarperusahaan menunjukkan semakin dikenal masyarakat yang berarti semakin mudah untuk mendapatkan informasi mengenai perusahaan. Kemudahan mendapatkan informasi akan meningkatkan kepercayaan investor dan mengurangi faktor ketidakpastian yang berarti risiko underpricing lebih kecil dan ekspetasi intial return lebih rendah. Ada kecenderungan bahwa perusahaan berukuran kecil mengalami abnormal return yang besar dibandingkan dengan perusahaan besar. Rodoni (2002) yang membuktikan bahwa perusahaan berukuran kecil cenderung mengalami underpricing dibandingkan dengan perusahaan besar.

Menurut Weston dan Copeland (1999), keputusan menyangkut besarnya perusahaan akan berakibat pada tingkat harga saham perusahaan. Besar kecilnya suatu perusahaan akan berpengaruh kepercayaan investor, dimana perusahaan yang semakin besar cenderung akan menguasai banyak akses informasi, sehingga akan meningkatkan kepercayaan investor. Sujoko dan Ugi (2007) menemukan bahwa ukuran perusahaan mempunyai pengaruh positif signifikan terhadap nilai perusahaan hal ini sejalan dengan penelitian Lin (2006), Rodoni (2002), Pangemanan dan Mawikere (2011) dimana perusahaan besar lebih menjanjikan kinerja, prospek yang baik dalam jangka waktu yang lama dan mencerminkan perusahaan relatif lebih stabil dan lebih mampu menghasilkan laba dibanding perusahaan dengan total asset yang kecil.

Investor dalam menginvestasikan dananya akan bersikap rasional, sehingga aspek fundamental akan menjadi dasar penilaian (basic valuation) yang utama. Kinerja keuangan perusahaan merupakan salah satu faktor yang dilihat oleh calon investor untuk menentukan investasi saham. Baik buruknya kinerja keuangan yang dimiliki oleh perusahaan dapat dilihat dari laporan keuangannya. Kinerja keuangan perusahaan merupakan salah satu faktor yang dilihat oleh calon investor untuk menentukan investasi saham.

Hal ini karena kinerja keuangan yang tercermin dari laporan keuangan perusahaan menginformasikan kondisi keuangan perusahaan sekarang dan masa lalu, yang dapat digunakan untuk memprediksikan kondisi perusahaan di masa yang akan datang. Laporan keuangan yang dijadikan sebagai salah satu alat pengambilan keputusan yang andal dan bermanfaat, sehingga laporan keuangan haruslah memiliki kandungan informasi yang bernilai tinggi bagi penggunanya. Berdasarkan laporan keuangan tersebut investor dapat melakukan proses penilaian (valuation) saham yang mencerminkan hubungan antara risiko dan hasil pengembalian yang sesuai dengan preferensi masing-masing jenis saham.

Salah satu informasi yang dari laporan keuangan, investor akan mengetahui bagaimana tingkat profitabilitas perusahaan. Profitabilitas menunjukkan kemampuan perusahaan dalam menghasilkan laba. Profitabilitas yang tinggi menunjukkan prospek perusahaan baik, sehingga investor akan merespon positif sinyal tersebut dan nilai perusahaan akan meningkat (Sujoko \& Ugi, 2007). Miller dan Modigliani (1961) menyatakan bahwa nilai perusahaan ditentukan oleh earnings power dari aset perusahaan. Dimana semakin tinggi earnings power maka semakin efisien perputaran aset dan atau semakin tinggi profit margin yang diperoleh perusahaan yang akan berdampak 
Sugeng Haryanto / Identifikasi Ekspektasi Investor melalui Kebijakan Struktur Modal ...

pada nilai perusahaan. Beberapa hasil penelitian menunjukkan bahwa profitabilitas berpengaruh positif signifikan terhadap nilai perusahaan (Ayuningtias \& Kurnia, 2013; Ratih, 2011).

Bagi sebuah perusahaan, menjaga dan meningkatkan kinerja keuangan adalah suatu keharusan agar saham tersebut tetap eksis dan tetap diminati oleh investor (Mahendra et al. 2012). Hal inikarena nilai saham mencerminkan nilai perusahaan, tidak hanya nilai intrinsik pada suatu saat, tetapi juga mencerminkan harapan akan kemampuan perusahaan dalam meningkatkan kemakmuran di masa yang akan datang. Kinerja keuangan berpengaruh positif terhadap nilai perusahaan (Emirzon, 2006; Wardani \& Hermuningsih, 2011; Haryanto, 2011; Mahendra et al., 2012). Namun Putra et al. (2010) menunjukkan bahwa profitabilitas tidak berpengaruh signifikan terhadap nilai perusahaan.

Nilai perusahaan mencerminkan kesejahteraan pemilik. Manager, sebagai wakil dari pemilik, bertanggung jawab untuk mengelola dalam rangka meningkatkan nilai perusahaan. Optimalisasi nilai perusahaan dapat dilakukan dengan prinsip tata kelola perusahaan yang baik, melalui pelaksanaan fungsi manajemen keuangan, dimana satu keputusan keuangan yang diambil akan mempengaruhi keputusan keuangan lainnya dan berdampak pada nilai perusahaan. Pemicu utama berkembangnya kebutuhan akan praktik-praktik tata kelola perusahaan yang baik atau Good Corporate Governance (GCG) adalah sebagai akibat terjadinya kebangkrutan perusahaan-perusahaan. Menurut kajian yang dilakukan peneliti terdahulu, isu corporate governance dilatar belakangi adanya teori agency (Agency Theory) yang menyatakan bahwa permasalahan agency (Agency problem) muncul ketika kepengurusan suatu perusahaan terpisah dari pemiliknya.

Agency problem muncul sebagai akibat adanya hubungan antara agent dengan principle ketika timbul konflik antara harapan dan tujuan principle dari para direksi. Dalam agency theory yang dikemukakan oleh Jensen dan Mekling
(1976), yaitu adanya perbedaan kepentingan antara agent dan principal. Agent dalam suatu perusahaan diberi kewenangan untuk mengurus jalannya perusahaan dan mengambil keputusan atas nama pemilik, namun agent tersebut mempunyai kepentingan yang berbeda dengan pemegang saham. Pemilik atau pemegang saham, dimana principal memberi kekuasan kepada agent untuk mengelola perusahaan, menghendaki laporan keuangan yang sebenarnya. Namun manajemen seringkali bertindak tidak seperti yang diharapkan oleh pemegang saham karena juga memiliki kepentingan sendiri, yaitu meningkatkan kemakmuran manajemen sendiri.

Dewan Komisaris yang berperan sebagai agent dalam suatu perusahaan diberi kewenangan untuk mengurus jalannya perusahaan dan mengambil keputusan atas nama pemilik, namun agent tersebut mempunyai kepentingan yang berbeda dengan pemegang saham (pemilik). Para pemilik mengalami kesulitan untuk memverifikasi apa yang sesungguhnya dikerjakan manajemen dan juga ketika pemilik dan direksi mempunyai sikap yang berbeda terhadap risiko.

Sedangkan menurut Tjager et al. (2003), sentralisasi isu corporate governance dilatar belakangi beberapa permasalahan diantaranya adanya tuntutan akan transparansi dan independensi itu terlihat adanya tuntutan perusahaan agar memiliki lebih banyak komisaris independen yang mengawasi tindakan-tindakan para eksekutif. Prinsip-prinsip GCG juga berfungsi untuk mengendalikan perilaku pengelola perusahaan agar tidak hanya menguntungkan diri sendiri tetapi juga menguntungkan pemilik perusahaan. Kepentingan pemilik dana adalah memperoleh return yang memadai atas dana yang ditanamkan (Gunarsih, 2010).

GCG merupakan tata kelola perusahaan yang menjelaskan hubungan antara berbagai partisipan dalam perusahaan yang menentukan arah kinerja perusahaan. Lima prinsip GCG meliputi transparansi, akuntabilitas, responsiveness, independensi dan fairness 
dengan baik. Stakeholder perusahaan, yang meliputi para pemagang saham, karyawan, rekanan bisnis, konsumen, investor yang akan merasakan dan menilai praktik GCG yang dijalankan suatu perusahaan. Investor jangka panjang pada umumnya akan melihat dari berbagai aspek, baik fundamental perusahaan, kinerja operasional, harga saham dan valuasi, sehingga prinsip GCG akan menjadi perhatian penting.

Penerapan GCG yang baik menjadi sebuah indikator penting bagi para pelaku pasar modal, karena akan memberikan rasa aman untuk menanamkan investasinya pada emiten. Investor memerlukan informasi yang lengkap, akurat dan tepat waktu untuk mendukung keputusan investasi yang akan diambil. Perusahaan akan menginformasikan dan memastikan bahwa dana yang investor investasikan untuk kegiatan pembiayaan, investasi dan pertumbuhan perusahaan secara tepat dan seefisien mungkin. Manajemen juga memastikan mengambil kebijakan yang terbaik untuk kepentingan perusahaan.

GCGjugaberfungsiuntukmenumbuhkan kepercayaan Investor terhadap perusahaan (Emirzon, 2006). Jika perusahaan mempunyai komitmen dan konsistensi menjalankan prinsip GCG dalam aktivitas perusahaannya dengan sendirinya menumbuhkan kepercayaan investor. Prinsip-prinsip GCG juga berfungsi untuk mengendalikan perilaku pengelola perusahaan agar tidak hanya menguntungkan diri sendiri tetapi juga menguntungkan pemilik perusahaan. Kepentingan pemilik dana adalah memperoleh return yang memadai atas dana yang ditanamkan (Gunarsih, 2010). Sampai saat ini memang belum ada benchmark untuk melihat korelasi antara investasi (di pasar saham) dengan GCG, namun jika suatu perusahaan menerapkan GCG secara berkelanjutan pamor perusahaan tersebut diyakini akan turut membaik dan berdampak positif di lantai Bursa (Swa, XXVIII 20 Desember 2012-9 Januari 2013).

Cara perusahaan menerapkan dan melaksanakan GCG menjadi sangat penting untuk meyakinkan investor, karena akan mampu menekan tingkat risiko investasi. Kunci penting adalah bagaimana menjadikan GCG sebagai roh yang menggerakkan perusahaan dalam melaksanakan operasionalnya, tidak hanya pada level awareness, tetapi sudah embedded pada setiap insan perusahaan. Di Indonesia dalam upaya peningkatan $G C G$, telah dilakukan penilaian indeks tata kelaola perusahaan setiap tahunnya. Perusahaan yang mengikuti ajang ini akan masuk dalam Indonesia Most Trusted Companies Based On Corporate Governance Perception Indx (CGPI).

Darmawati dan Rahayu (2004) serta Lukviarman (2004) mengkaji hubungan antara corporate governance dengan nilai perusahaan dengan menggunakan ukuran tingkat pengembalian aset (ROA) dan Tobins-Q. Mereka menemukan bahwa GCG mempunyai hubungan yang signifikan terhadap tingkat pengembalian asset tetapi tidak signifikan terhadap Tobin-Q. Hasil ini sejalan dengan Tumirin (2007) penerapan GCG akan mempengaruhi tercapainya nilai perusahaan. Sedangkan Wardoyo dan Veronica (2013) menemukan bahwa GCG yang diukur dengan dewan direksi, berpengaruh terhadap nilai perusahaan. Sedangkan GCG yang diukur dengan dewan komisaris dan jumalh anggota komite audit, tidak berpengaruh terhadap nilai perusahaan. Sedangkan Ratih (2011) menunjukkan bahwa GCG tidak berpengaruh terhadap nilai perusahaan. Dengan demikan dapat disusun kerangka pikir seperti ditunjukkan pada Gambar 1.

Berdasarkan analisis terhadap penelitianpenelitian sebelumnya seperti telah dijelaskan sebelumnya, maka dapat dirumuskan beberapa hipotesis. Hipotesis yang pertama adalah DER berpengaruh terhadap nilai perusahaan. Kemudian, hipotesis yang kedua adalah bahwa ukuran perusahaan berpengaruh terhadap nilai perusahaan. Sedangkan hipotesis yang ketiga adalah bahwa ROA berpengaruh terhadap nilai perusahaan dan hipotesis yang terakhir adalah bahwa CGPI berpengaruh terhadap nilai perusahaan. Sehingga tujuan yang 


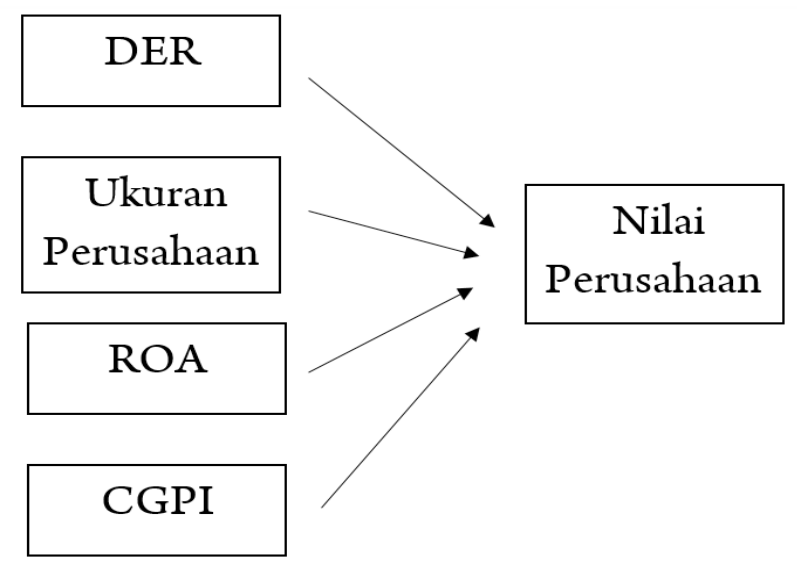

Gambar 1. Kerangka Pikir

Sumber: Modigliani dan Miller (1963), Jandik dan Makhija (2005), Sujoko dan Ugi (2007), Lin (2006), Rodoni (2002), Pangemanan dan Mawikere (2011), Ayuningtias dan Kurnia (2013), Ratih (2011), Darmawati, Khomsiyah, dan Rahayu (2004) dan Lukviarman (2004).

ingin dicapai dalam penelitian ini yaitu: (1) mengetahui pengaruh kebijakan struktur modal terhadap ekspektasi investor; (2) mengetahui pengaruh ukuran perusahaan terhadap ekspektasi investor; (3) mengetahui pengaruh profitabilitas perusahaan terhadap ekspektasi investor; serta 4) mengetahui pengaruh GCPI terhadap ekspektasi investor.

\section{METODE}

Penelitian ini menggunakan pendekatan kuantitatif yaitu yang melakukan pengujian terhadap hubungan kausal dari variabel-variabel penelitian yang terukur (paraitermetrik). Dimana objek penelitian ini adalah yang masuk pemeringkatan The Indonesia Most Trusted Companies-Corporate Governance Perception Index Majalah Swa tahun 2012 dan 2013. Populasi dalam penelitian ini adalah perusahaan yang masuk dalam penilaian GCPI. Teknik sampling yang digunakan purposive sampling, dengan kriteria: perusahaan tersebut telah go publik sebelum tahun 2012; mempublikasikan laporan keuangan tahun 2012 dan 2013 serta kelengkapan data lain yang dibutuhkan dalam penelitian ini.
Variabel yang digunakan dalam penelitian ini adalah Dependent variable: yaitu ekspektasi investpor yang diukur dengan nilai perusahaan. Nilai perusahaajn dalam penelitian ini diproxikan dengan nilai price earning ratio (PER). PER merupakan perbandingan antara laba bersih perlembar saham dengan harga pasar saham. Semakin tinggi nilai PER mengindikasikan kepercayaan investor terhadap suatu perusahaan semakin tinggi.

$$
\text { PER }=\frac{\text { Price }}{\text { Earning Per Share }}
$$

Sedangkan Independent variabel yang digunakan dalam penelitian ini adalah kebijkan perusahaan yang diproxikan dengan debt to equity ratio (DER) $\left(\mathrm{X}_{1}\right)$. DER merupakan perbandingan antara jumlah hutang dengan besarnya ekuitas perusahaan. Semakin tinggi DER menunjukkan semakin tinggi kewajiban perusahaan dibandingkan dengan equitas.

$$
D E R=\frac{\text { Hutang }}{\text { Equity }}
$$


Ukuran perusahaan menggambarkan besar kecilnya suatu perusahaan yang dapat dinilai dari total asset yang dimiliki perusahaan. Ukuran perusahaan diproxikan dengan 1/ logaritma natural total Aktiva (Neiker, 2008) $\left(\mathrm{X}_{2}\right)$.

\section{Ukuran Perusahaan $=\frac{1}{\text { Ln Total Aktiva }}$}

Profitabilitas yang diproxikan dengan nila ROA $\left(\mathrm{X}_{3}\right)$. ROA merupakan perbandingan antara net income dengan total asset perusahaan, semakin tinggi ROA semakin tinggi pula kemampuan perusahaan menghasilkan laba dengan menggunakan asset yang dimilik, semakin tinggi ROA menunjukkan semakin tinggi tingkat profitabilitas suatu perusahaan. Secara matematis ROA dapat dirumuskan:

$$
R O A=\frac{\text { Earning After Tax }}{\text { Total Asset }}
$$

Corporate Governance Perception Index (CGPI) $\left(\mathrm{X}_{4}\right)$, variable ini menunjukkan indeks tatat kelola suatu perusahaan, yang terdiri dari 5 (lima) aspek penilaian: transparansi, akuntabilitas, responsibilitas, independensi dan keadilan.

Data yang digunakan dalam penelitian ini merupakan data sekunder yang berupa laporan keuangan, harga saham dari perusahaan yang go public di Bursa Efek Indonesia dan nilai CGPI yang dipublikasikan oleh Majalah Swa. Teknik pengumpulan data dilakukan dengan dokumentasi dari Indonesia Capital Market Directory (ICMD), situs idx.co.id dan Majalah Swa.

Pengujian asumsi klasik dilakukan untuk mengetahui kelayakan model regresi yang digunakan dalam penelitian ini. Uji asumsi klasik dilakukan untuk memastikan dalam model regresi tidak terdapat autokorelasi, multikolineritas dan heteroskedastisitas serta datanya berdistribusi normal (Ghozali, 2005).
Secara sistematis model yang dikembangkan untuk menganalisis pengaruh variabel kebijakan struktur modal, ukuran perusahaan, profitabilitas dan GCPI terhadap nilai perusahaan digunakan model regresi berganda. Untuk pengujian hipotesis dilakukan uji $\mathrm{F}$, dan uji $\mathrm{t}$ serta koefisien determinasi dengan menggunakan SPPS verrsi 18. Model tersebut dirumuskan sebagai berikut:

$$
\begin{aligned}
& \mathrm{Y}=\alpha+\beta 1 \mathrm{X} 1+\beta 2 \mathrm{X} 2+\beta 3 \mathrm{X} 3+\beta 4 \mathrm{X} 4+\varepsilon \\
& \text { Keterangan: } \\
& \mathrm{Y}=\text { Ekspektasi Investor } \\
& \mathrm{a}=\text { Konstanta } \\
& \beta_{1-4}=\text { Koefisien regresi } \\
& \mathrm{X}_{1}=\text { Kebijakan struktur modal } \\
& \mathrm{X}_{2} \quad=\text { Ukuran perusahaan } \\
& \mathrm{X}_{3} \quad=\text { Profitabilitas } \\
& \mathrm{X}_{4} \quad=\text { Corporate Governance } \\
& \text { Perception Index } \\
& \varepsilon=\text { Error }
\end{aligned}
$$

\section{HASIL DAN PEMBAHASAN}

Deskripsi data penelitian disajikan pada Tabel 1. Berdasarkan Tabel 1 menunjukkan Tingkat profitabilitas perusahaan yang menggambarkan kinerja perusahaan (ROA) tertinggi sebesar 40.38 yang diperoleh oleh PT Unilever Tbk. Rerata kebijakan Struktur modal (DER) sebesar 3,21. Hal ini menunjukkan bahwa besarnya hutang dibandingkan dengan equity perusahaan sebesar 3,21 kali. DER tertinggi sebesar 12,1, yaitu pada Bank CIC. Rata-rata DER tertinggi terjadi pada perusahaan perbankan, yaitu bank Niaga (BNGA), Bank Mandiri (BMRI), Bank BNI (BBNI), Bank BTN (BBTN, Bank NISP, bank BRI, Bank BBNP, Bank Jabar dan Banten (BJBR).

Tingginya rata-rata DER pada industri perbankan, dikarenakan karakteristik bank yang merupakan lembaga intermediasi. Dimana sumber dana masyarakat atau DPK yang merupakan hutang bagi suatu bank sangat besar. Sedangkan rata-rata Ukuran perusahaan 
Tabel 1. Diskripsi data Penelitian

\begin{tabular}{|c|c|c|c|c|c|c|}
\hline N0 & Perusahaan & $\mathrm{ROA}$ & DER & UKPER & CGPI & PER \\
\hline 1 & ANTM & 0.152 & 0.41 & 0.060 & 86.56 & 14.57 \\
\hline 2 & BNGA & 0.029 & 8.08 & 0.053 & 89.88 & 17.55 \\
\hline 3 & BMRI & 0.025 & 7.81 & 0.050 & 91.91 & 11.99 \\
\hline 4 & BBNI & 0.021 & 6.90 & 0.051 & 85.75 & 10.36 \\
\hline 5 & NISP & 0.012 & 8.08 & 0.056 & 85.86 & 17.49 \\
\hline 6 & BBTN & 0.012 & 11.17 & 0.055 & 85.9 & 11.17 \\
\hline 7 & GIAA & 0.058 & 1.39 & 0.060 & 85.84 & 19.22 \\
\hline 8 & TLKM & 0.165 & 0.69 & 0.054 & 89.57 & 9.68 \\
\hline 9 & UNTR & 0.117 & 0.69 & 0.057 & 87.77 & 11.95 \\
\hline 10 & ADMF & 0.055 & 2.82 & 0.060 & 78.19 & 6.66 \\
\hline 11 & AUTO & 0.128 & 0.47 & 0.063 & 79.09 & 13.12 \\
\hline 12 & BNBR & 0.023 & 1.07 & 0.059 & 76.23 & 13.91 \\
\hline 13 & BTEL & -0.347 & 1.80 & 0.061 & 75.74 & -1.17 \\
\hline 14 & BCIC & 0.028 & 12.10 & 0.061 & 78.84 & 7.41 \\
\hline 15 & BBNP & 0.01 & 10.28 & 0.064 & 79.93 & 6.14 \\
\hline 16 & BBRI & 0.034 & 8.43 & 0.050 & 84.16 & 9.43 \\
\hline 17 & BJBR & 0.018 & 9.11 & 0.056 & 77.79 & 8.15 \\
\hline 18 & PTBA & 0.229 & 0.41 & 0.062 & 82.56 & 11.82 \\
\hline 19 & BUMI & -0.092 & 5.26 & 0.056 & 72.8 & -13.67 \\
\hline 20 & JSMR & 0.062 & 1.32 & 0.059 & 83.66 & 22.04 \\
\hline 21 & TINS & 0.071 & 0.43 & 0.064 & 75.68 & 15.52 \\
\hline 22 & BRAU & 0.046 & 2.93 & 0.060 & 65.95 & -23.94 \\
\hline 23 & MTLA & 0.101 & 0.28 & 0.070 & 66.51 & 23.37 \\
\hline 24 & PANR & 0.037 & 1.92 & 0.074 & 68.9 & 7.27 \\
\hline 25 & ASII & 12.48 & 1.03 & 0.053 & 74.76 & 13.70 \\
\hline 26 & BMRI & 2.52 & 7.31 & 0.049 & 74.46 & 11.63 \\
\hline 27 & TLKM & 16.49 & 0.66 & 0.054 & 74.01 & 9.92 \\
\hline 28 & PGAS & 23.42 & 0.66 & 0.057 & 73.67 & 12.61 \\
\hline 29 & UNTR & 11.44 & 0.56 & 0.056 & 73.30 & 12.54 \\
\hline 30 & TRIO & 7.14 & 1.90 & 0.065 & 73.19 & 12.36 \\
\hline 31 & INTP & 20.93 & 0.17 & 0.059 & 73.07 & 17.35 \\
\hline 32 & UNVR & 40.38 & 2.02 & 0.061 & 72.90 & 32.87 \\
\hline 33 & INDF & 8.06 & 0.74 & 0.056 & 72.66 & 10.54 \\
\hline 34 & SMGR & 18.54 & 0.46 & 0.058 & 72.46 & 19.09 \\
\hline 35 & HMSP & 37.89 & 0.97 & 0.059 & 72.44 & 26.78 \\
\hline 36 & KRAS & -0.76 & 1.30 & 0.059 & 72.32 & -35.06 \\
\hline 37 & BRMS & -2.99 & 0.36 & 0.060 & 72.17 & -10.90 \\
\hline 38 & BBRI & 3.39 & 7.50 & 0.050 & 72.07 & 9.18 \\
\hline 39 & PTBA & 22.86 & 0.50 & 0.061 & 71.60 & 15.33 \\
\hline
\end{tabular}


Tabel 1.Lanjutan

\begin{tabular}{llrrrrr}
\hline N0 & Perusahaan & \multicolumn{1}{c}{ ROA } & \multicolumn{1}{c}{ DER } & UKPER & \multicolumn{1}{l}{ CGPI } & \multicolumn{1}{c}{ PER } \\
\hline 40 & ANTM & 15.19 & 0.54 & 0.060 & 71.40 & 4.08 \\
41 & GGRM & 9.80 & 0.56 & 0.057 & 71.34 & 26.62 \\
42 & GJTL & 8.80 & 1.35 & 0.061 & 71.22 & 7.14 \\
43 & KLBF & 18.85 & 0.28 & 0.062 & 70.19 & 30.38 \\
44 & BBCA & 2.65 & 7.52 & 0.050 & 69.90 & 18.86 \\
45 & GIAA & 4.40 & 1.26 & 0.059 & 69.89 & 10.63 \\
46 & BBNI & 2.11 & 6.66 & 0.051 & 69.15 & 9.58 \\
47 & JSMR & 6.20 & 1.53 & 0.059 & 68.65 & 24.12 \\
48 & BDMN & 2.64 & 4.26 & 0.053 & 67.99 & 13.27 \\
\hline & Rerata & 6.113 & 3.21 & 0.0579 & 76.25 & 11.097 \\
& Tertinggi & 40.38 & 12.10 & 0.0738 & 91.91 & 32.87 \\
\hline
\end{tabular}

Sumber: Majalah Swa dan Swa 27 XXIX 19 Desember 2013-8 Januari 2014 dan Swa 27 XXVII 20 Desember 2012-9 Januari 2013 dan data diolah.

yang diukur dengan menggunakan 1/logaritma natural dari total aktiva sebesar sebesar 0.0579 . Sedangkan CGPI sebesar 76.25, dengan nilai CGPI tertinggi sebesar 91.91, yaitu Bank Mandiri. Ekspektasi investor yang ditunjukkan dengan nilai PER reratanya sebesar 11.097 dengan nilai PER tertinggi pada perusahaan PT Unilever Tbk dengan niali PER 32.87.

Pengujian normalitas data dilakukan dengan menggunakan melihat diagram normal p-plot. Jika data menyebar mengikuti arah garis diagonal, maka data normal. Model regresi yang baik adalah distribusi datanya normal atau mendekati normal. Hasil pengujian normalitas data ditunjukkan pada Gambar 2.

Pengujian heteroskedastisitas dilakukan dengan menggunakan scatter plot antar nilai prediksi yang distandarisari (ZPRED) dengan nilai residual yang distandarisasi (SRESID). Uji ini untuk mengetahui apakah terdapat hubungan antara variabel bebas dengan nilai residual. Pengujian terhadap asumsi klasik menunjukkan bahwa tidak terjadi heteroskedasitas, hal ini ditunjukkan Gambar 3. scatterplot, dimana sebaran atau plot di scatter plot menunjukkan menyebar dan tidak membentuk suatu pola tertentu atau menyebar di atas dan di bawah angka nol pada sumbu studentized residual atau sumbu Y dan di kanan dan kiri sumbu standardized predicted value.
Pengujian autokorelasi dengan menggunakan DW. Hasil analisis menunjukkan nilai DW sebesar 1.925 (Tabel 2), dengan jumlah data (n) sebanyak 48 dan tabel Durbin Watson dengan signifikansi 0,05 diperoleh nilai dU 1,7206 dan dL sebesar 1,3619. Nilai DW hitung berada diantara dU $(1,7206)$ dan 4-dU $(2,2794)$ sehingga dapat disimpulan tidak terjadi autokorelasi.

Sedangkan untuk pengujian multikolineritas dengan menggunakan nilai Varian Inflation Factor (VIF) menunjukkan nilai VIFnya (Tabel 2) tidak ada yang lebih besar dari 10, masing-masing nilai VIF DER 1,473 , ukuran perusahaan 1,316 , ROA 1,271 dan GCPI sebesar 1,257. Nilai VIF yang di bawah 10, sehingga dapat disimpulkan tidak terjadi multikolineritas.

\section{Pengujian Hipotesis}

Pengujian good fit of model dengan melihat Tabel 2 menunjukkan bahwa secara simultan variabel kebijakan struktur modal (DER), ukuran perusahaan, profitabilitas (ROA) dan Corporate Governance Perception Index (GCPI) berpengaruh terhadap ekspetasi investor yang proksikan dengan nilai perusahaan (PER). Hal ini ditunjukkan dengan nilai probabilitas F sebesar 0,006, dimana nilainya lebih kecil 
Sugeng Haryanto / Identifikasi Ekspektasi Investor melalui Kebijakan Struktur Modal ...

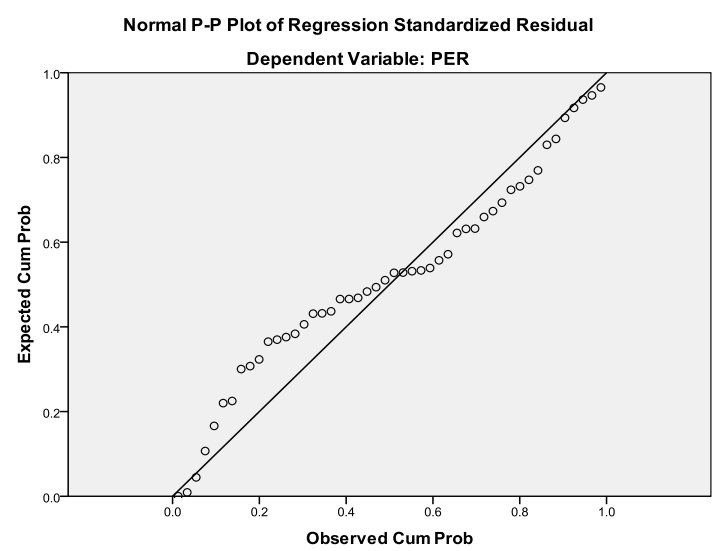

Gambar 2. Uji Normalitas Data

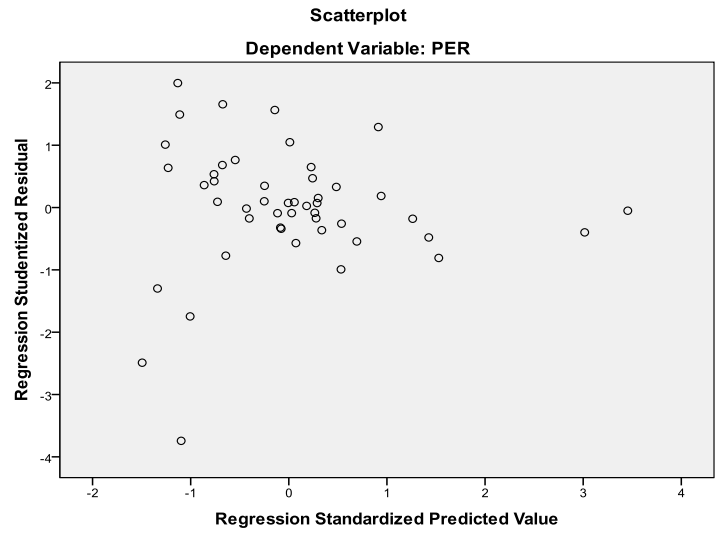

Gambar 3. Uji Heteroskedastisitas

Tabel 2. Hasil Analisis

\begin{tabular}{|c|c|c|c|c|c|c|c|}
\hline \multirow[t]{2}{*}{ Model } & \multicolumn{2}{|c|}{$\begin{array}{l}\text { Unstandardized } \\
\text { Coefficients }\end{array}$} & \multirow{2}{*}{$\begin{array}{c}\begin{array}{c}\text { Standardized } \\
\text { Coefficients }\end{array} \\
\text { Beta }\end{array}$} & \multirow[t]{2}{*}{$\mathrm{t}$} & \multirow{2}{*}{ Sig. } & \multirow[t]{2}{*}{ VIF } & \multirow[t]{2}{*}{ Keterangan } \\
\hline & $\mathrm{B}$ & Std. Error & & & & & \\
\hline Constant & $-51,001$ & 31,860 & & -1.601 & 0,117 & & \\
\hline DER & 0,163 & 0,541 & 0,047 & 0,302 & 0,764 & 1,473 & Tidak Signifikan \\
\hline UKPER & 243,594 & 354,923 & 0,102 & 0,686 & 0,496 & 1,316 & Tidak signifikan \\
\hline $\mathrm{ROA}$ & 0,685 & 0,178 & 0,562 & 3,856 & 0,000 & 1,271 & Signifikan \\
\hline CGPI & 0,568 & 0,257 & 0,321 & 2,211 & 0,032 & 1,257 & Signifikan \\
\hline $\begin{array}{l}\text { F Hitung } \\
\text { Probablita } \\
\text { R Square } \\
\text { Dependen }\end{array}$ & $\begin{array}{r}: 4 \\
(\operatorname{sig}): 0 \\
: 0 \\
\text { Variable }\end{array}$ & $\begin{array}{l}193 \\
006 \\
281 \\
\text { PER }\end{array}$ & & & & & \\
\hline
\end{tabular}

Sumber: data yang diolah (2014) 
dari 0,05. Sedangkan unutk uji secara parsial menunjukkan bahwa uji hipotesis 1 untuk variabel kebijakan struktur modal (DER) terhadap PER nilai probabilitas lebih besar dari 0,05 , yaitu sebesar 0,764 sehingga dapat disimpulkan DER tidak berpengaruh terhadap PER. Untuk hipotesis 2, yaitu pengaruh ukuran perusahaan terhadap PER menunjukkan nilai probabilitasnya di atas 0,05 sehingga dapat disimpulkan ukuran perusahaan tidak berpengaruh terhadap PER. Sedangkan untuk hipotesis 3 dan 4 , yaitu pengaruh ROA terhadap PER dan GCPI terhadap PER menunjukkan nilai probabilitasnya masing-masing lebih kecil dari 0,05, yaitu 0,000 dan 0,032 sehingga dapat disimpulkan ROA dan GCPI berpengaruh terhadap PER.

Nilai koefisien determinasi, yang ditunjukkan dengan nilai $\mathrm{R}^{2}$ sebesar 0,281. Hal ini menunjukkan bahwa variabel DER, Ukuran perusahaan, ROA dan GCPI mampu menjelaskan varian PER sebesar 28,1 persen, sedang sisanya 71,9 dijelaskan oleh variabel lain diluar model. PER yang merupakan ekspektasi investor, dihitung dari perbandingan antara harga saham di pasar dengan laba perlembar saham. Nilai koefisien determinasi yang hanya sebesar 28,1 menunjukkan bahwa ekspektasi investor terkait harga saham, selain mempertimbangkan aspek fundamental perusahaan juga aspek teknikal.

\section{Pengaruh Kebijakan Struktur Modal (DER) Terhadap Ekspektasi Investor (PER)}

Hasil pengujian secara parsial menunjukkan bahwa kebijakan struktur modal (DER) tidak berpengaruh terhadap ekspektasi investor (PER). Kebijakan struktur modal menunjukkan bagaimana manajemen menentukan sumber dana bagi perusahaan. Kebijakan struktur modal yang diambil manajemen akan mempertimbangkan cost of fund-nya, sehingga akan mempengaruhi risiko dan return perusaahaan di masa yang akan datang. Struktur modal yang optimal adalah struktur modal yang mengoptimalkan keseimbangan antara risiko dan pengembalian, sehingga memaksimumkan harga saham. Dalam manajemen keuangan, utang yang besar akan dapat mengurangi pembayaran pajak (tax deductable). Penghematan pajak akan diterima secara kontinue. Penghematan pajak inilah yang merupakan kelebihan nilai perusahaan yang menggunakan utang dibanding dengan perusahaan yang tanpa menggunakan utang.

Kebijakan struktur modal (DER) yang tidak berpengaruh terhadap ekspekasi investor terjadikarena secara umum yang mempengaruhi keputusan investor untuk membeli saham adalah rasional yang umumnya berkaitan dengan aspek fundamental dari perusahaan yang memasuki pasar modal seperti profitabilitas dan laba yang diperoleh perusahaan. Struktur modal yang besar pada pada penelitian ini karena didominasi oleh struktur modal industri perbankan dalam sampel penelitian. Tingginya DER pada industri perbankan dikarenakan bank memiliki kewajiban untuk memiliki simpanan masyarakat atau Dana Pihak Ketiga (DPK).

Hasil penelitian ini tidak mendukung proposisi Modigliani dan Miller (1963), penelitian Meythi et al. (2012) dan Sugihen (2003) menunjukkan bahwa struktur modal berpengaruh terhadap nilai perusahaan. Serta Jandik dan Makhija (2005) dalam pandangannya tentang pengaruh struktur modal terhadap nilai perusahaan, yaitu alignment effect dan entranchment. Dalam analisis alignment effect bahwa struktur modal yang didanai dengan hutang dapat meningkatkan nilai perusahaan. Namun hasil ini mendukung penelitian yang dilakukan oleh Bukit (2012) dan Kesuma (2009) dimana struktur modal tidak berpengaruh terhadap nilai perusahaan.

\section{Pengaruh Ukuran Perusahaan Terhadap Eks- pektasi Investor (PER)}

Ukuran perusahaan menunjukkan besar kecilnya suatu perusahaan yang dapat dinilai dari total assets yang dimiliki. Perusahaan yang besar akan cenderung memiliki keluasaan dalam melakukan ekspansi, karena didukung 
Sugeng Haryanto / Identifikasi Ekspektasi Investor melalui Kebijakan Struktur Modal ...

oleh aset yang besar. Hasil penelitian ini menunjukkan bahwa ukuran perusahan tidak berpengaruh terhadap nilai perusahaan. Hal ini menunjukkan bahwa ekspektasi investor terhadap suatu perusahaan yang tercermin dari seberapa besar rupiah yang mau dibayarkan investor untuk membeli saham cenderung kurang memperhatikan besarnya suatu perusahaan. Hal ini dapat terjadi bahwa belum tentu perusahaan-perusahaan yang memiliki asset besar, mampu menghasilkan keuntungan yang tinggi pula.

Penelitian ini menunjukkan bahwa perusahaan-perusahaan yang mempunyai asset besar adalah perusahaan perbankan yang didanai dari DPK. Secara rata-rata menunjukkan bahwa industri perbankan dengan asset yang besar ternyata tingkat kemampulabaanya lebih rendah dibandingkan perusahaan non perbankan. Pada tahun 2012 Bank Mandiri memiliki asset sebesar Rp. 635,6 Trilyun, namun ROA-nya hanya sebesar 2,52. Sedangkan Bank BCA pada waktu sama asset sebesar Rp. 443 trilyun ROAnya sebesar 2,65. Jika dibandingkan dengan perusahaan pada periode yang sama dengan ROA yang pling besar yaitu Unilever yaitu sebesar 40,38 namun asetnya hanya $\mathrm{Rp} 11,995$ trilyun.

Hasil penelitian ini bertentangan dengan penelitiannya Lin (2006), Rodoni (2002), Pangemanan dan Mawikere (2011) dimana perusahaan besar lebih menjanjikan kinerja yang baik, perusahaan telah masuk tahap kedewasaan dimana dalam tahap ini ukuran perusahaan sudah positif dan dianggap memiliki prospek yang baik dalam jangka waktu yang relatif lama, selain itu juga mencerminkan bahwa perusahaan relatif lebih stabil dan lebih mampu menghasilkan laba dibanding perusahaan dengan total asset yang kecil. (Pangemanan dan Mawikere, 2011). Rodoni (2002) yang membuktikan bahwa perusahaan berukuran kecil cenderung mengalami underpricing dibandingkan dengan perusahaan besar.
Pengaruh Profitabilitas (ROA) Terhadap Ekspektasi Investor (PER)

Tingkat profitabilitas diukur dengan ROA. Penggunaan ROA didasarkan karena ROA dapat mengukur efektifitas perusahaan dalam menghasilkan laba bersih dengan memanfaatkan aset yang dimiliki untuk menghasilkan laba tersebut, sehingga dapat menjadi indikator keberhasilan perusahaan di pemandangan investor, sebagai mana yang dilakukan Dwiaji (2011). Hasil penelitian menunjukkan bahwa profitabilitas yang diproksikan dengan ROA berpengaruh terhadap ekspektasi investor.

Hal ini menunjukkan bahwa investor dalam menanamkan dananya cenderung melihat bagaimana perusahaan mampu menghasilkan laba. Perusahaan yang mampu menghasilkan profitabilitas yangtinggicenderung memberikan sinyal yang positif bagi pasar atau investor tentang kondisi perusahaan di masa yang akan datang dan sebaliknya. Profitabilitas yang tinggi menunjukkan prospek perusahaan baik, sehingga investor akan merespon positif sinyal tersebut dan nilai perusahaan akan meningkat. Laba yang besar merupakan sentimen positif bagi investor sehingga harga saham meningkat, yang selanjutnya dengan meningkatnya harga saham membuat nilai perusahaan akan meningkat. Laba yang dihasilkan perusahaan, maka akan melahirkan sentimen positif yang sangat kuat pada para investor, sehingga nilai perusahaan juga akan meningkat relatif besar. Secara rasional investor akan melihat aspek fundamental dari perusahaan yang memasuki pasar modal seperti profitabilitas dan laba yang diperoleh perusahaan.

Hasil penelitian ini sejalan dengan Miller dan Modigliani (1961) menyatakan bahwa nilai perusahaan ditentukan oleh earnings power dari aset perusahaan. Dimana semakin tinggi earnings power maka semakin efisien perputaran aset dan atau semakin tinggi profit margin yang diperoleh perusahaan yang akan berdampak pada nilai 
perusahaan. Hasil penelitian Emirzon (2006), Ratih (2011), Wardani dan Hermuningsih (2011), Haryanto (2011, Mahendra et al. (2012) dan Ayuningtias dan Kurnia (2013), menunjukkan bahwa profitabilitas berpengaruh positif signifikan terhadap nilai perusahaan. Sehingga hasil penelitian ini tidak mendukung hasil penelitian Putra et al. (2010).

\section{Pengaruh Corporate Governance Perception Index (GCPI) Terhadap Ekspektasi Investor (PER)}

GCG merupakan mekanisme yang dirancang perusahaan untuk melakukan tata kelola perusahaan yang baik yang meliputi transparansi, akuntabilitas, responsibilitas dan keadilan. Dengan tata kelola perusahaan yang baik tertesbut diharapkan perushaan akan memiliki nilai tambah, yang selanjutnya akan membuat stakeholder merespon positif. Pengumuman perusahaan yang masuk dalam pemeringkatan Corporate Governance Perception Index merupakan salah satu faktor eksternal yang dapat mempengaruhi ekspektasi investor pada suatu perusahaan. Adanya pengumuman emiten pada Corporate Governance Perception Index yang disebut dengan Indonesia Most Trusted Companies akan menjadi sinyal bagi investor mengenai prospek perusahaan.

Hasil penelitian menunjukkan bahwa GCPI berpengaruh positif terhadap ekspektasi investor. Hal ini menunjukkan sinyal bahwa perusahaan yang menerapkan GCG kemudian ikut dalam penilaian akan direspon positif oleh investor. Hal ini menunjukkan penerapan GCG yang baik merupakan indikator penting bagi para pelaku pasar modal. Hal ini karena akan memberikan rasa aman bagi investor untuk menanamkan dananya pada emiten. Investor yang melihat aspek GCG dan fundamental merupakan investor jangka panjang. Penerapan GCG merupakan faktor penting bagi pelaku di pasar modal. Dengan penerapan GCG dapat pengelolaan perusahaan sesuai dengan rule of the game yang berlaku tanpa mengekang stakeholder dalam mengambil keputusan. Tata kelola yang baik dalam mengelola perusahaan sangat diperlukan karena akan menentukan masa depan perusahaan, khususnya terkait dengan aksi corporate, seperti keputusan investasi, pembelian dan penjualan anak perusahaan (Swa 27 XXIX 19 Desember 20138 Januari 2014).

Halinipenelitianini juga mengindikasikan bahwa dengan tata kelola perusahaan yang baik, akan mampu meningkatkan kepercayaan investor terhadap suatu perusahaan. Hal sesuai dengan penelitian Emirzon (2006), dimana tata kelola perusahaan yang baik atau GCG akan mampu berfungsi untuk menumbuhkan kepercayaan Investor terhadap perusahaan. Jika perusahaan mempunyai komitmen dan konsistensi menjalankan prinsip GCG dalam aktivitas perusahaannya dengan sendirinya menumbuhkan kepercayaan investor. $\mathrm{Hal}$ ini karena dengan penerapan prinsip-prinsip GCG pada suatu perusahaan akan dapat mengendalikan perilaku pengelola perusahaan agar tidak hanya menguntungkan diri sendiri tetapi juga menguntungkan pemilik perusahaan. Hasil penelitian ini juga mendukung hasil penelitian Tumirin (2007), Darmawati dan Rahayu (2004), Lukviarman (2004) serta hasil penelitian Wardoyo dan Veronica (2013).

Pengelolaan diperlukan karena tata kelola perusahaan yang baik akan berbanding lurus dengan tingkat ketidakpastian pengembalian investasi. GCG akan memberikan perlindungan efektif kepada pemegang saham dan kreditur untuk memperoleh kembali atas investasi yang wajar seefisien mungkin dan wajar. Seorang investor mempunyai kecenderungan akan keamanan dana yang akan diinvestasikan dan adanya kepastian terhadap dana yang diinvestasikan. Penerapan Good Corporate Governance (GCG) merupakan bentuk pengelolaan perusahaan yang baik, karena di dalamnya tercakup bentuk perlindungan terhadap kepentingan investor (pemegang saham) sebagai pemilik perusahaan dan kreditur sebagai penyandang dana ekstern. Hasil penelitian ini juga mendukung hasil penelitian (Sukasih \& Susilowati, 2011) dimana 
Sugeng Haryanto / Identifikasi Ekspektasi Investor melalui Kebijakan Struktur Modal ...

pelaksanaan GCG pada perusahaan mampu meningkatkan kinerja keuangan perusahaan dan pasar modal, sehingga investor merasa aman, jika investor merasa aman akan menurunkan besarnya cost of capital yang akan dikeluarkan perusahaan.

\section{SIMPULAN DAN SARAN}

Penelitian bertujuan melakukan menganalisis pengaruh kausalitas antara kebijakan struktur modal, ukuran perusahaan, profitabilitas yang diukur dengan ROA dan perapan GCG yang diukur dengan Good Corporate Perception Index (GCPI) terhadap ekspektasi investor yang diukur dengan nilai perusahaan. Dengan menggunakan analisis regresi berganda kebijakan struktur modal dan ukuran perusahaan tidak berpengaruh signifikan terhadap ekspektasi investor. Sedangkan profitabilitas yang diukur dengan ROA berpengaruh signifikan dengan arah porsitif terhadap ekspetasi investor.

Hal ini menunjukkan bahwa profitabilitas merupakan sinyal positif bagi investor terhadap prospek perusahaan di masa yang akan datang. GCPI berpengaruh signifikan dengan arah positif terhadap ekspektasi investor. GCPI yang tinggi menunjukkan adanya tata kelola perusahaan yang baik, sehingga akan menjadi sinyal positif bagi investor akan rasa aman terhadap investasi yang akan ditanamkan. Praktek GCG mampu mendorong manajemen menjalankan bisnis yang mengutamakan kelangsungan hidup perusahaan, kepentingan para pemangku kepentingan untuk memperoleh keuntungan dalam jangka panjang.

Saran yang dapat diberikan kepada perusahaan adalah agar majamenen memberdayakan asset perusahaan sehingga mampu meningkatkan profitabilitas perusahaan dan juga dapat mengimplementasikan GCG sebagai roh dan budaya perusahaan yang menggerakkan perusahaan dalam melaksanakan operasionalnya, tidak hanya pada level awareness, tetapi sudah embedded pada setiap insan perusahaan. Selanjutnya perusahaan mengikuti penilaian Corporate Governance Perception Index yang disebut dengan Indonesia Most Trusted Companies. Bagi investor dalam melakukan investasi perlu mempertimbangkan tingkat profitabilitas perusahaan sebagai sinyal prospek kedepan serta penerapan GCG sehingga akan menjadi sinyal keamanan investasinya karena perusahaan dieklola dengan baik. Untuk penelitian yang akan datang perlu dilakukan analisis dengan melakukan menambah variabel, dengan memasukkaan variabel penerapan GCG, rentang waktu serta perlu dilakukan pemisahan perusahaan dengan melihat karakteristik industri.

\section{DAFTAR PUSTAKA}

Artini, S. L. G \& Puspaningsih, N. L. A. 2011. Struktur Kepemilikan dan Struktur Modal Terhadap Kebijakan Dividen dan Nilai Perusahaan. Jurnal Keuangan dan Perbankan. 15: 66-75.

Ayuningtias, D \& Kurnia. 2013. Pengaruh Profitabilitas terhadap Nilai Perusahaan: Kebijakan Dividend dan Kesempatan Investasi Sebagai Variabel Antara. Jurnal Ilmu dan Riset Akuntansi. 1(1).

Bukit, B. R. 2012. Pengaruh Struktur Modal Terhadap Nilai Perusahaan melalui Profitabilitas: Analisis Data Panel Perusahaan Manufaktur di Bursa Efek Indonesia. Jurnal Keuangan dan Bisnis. 4(3).

Darmawati, D. K \& Rahayu, R. G. 2004. Hubungan Good Corporate Governance dan Kinerja Perusahaan. Simposium Nasional Akuntansi VII. Denpasar, Bali. 2-3 September. pp: 391407.

Dwiaji, Y. C. 2011. Analisis Pengaruh Profitabilitas terhadap Keputusan Keuangan dan Dampaknya pada Nilai Perusahaan IndustriIndustri yang Terdaftar Di PT Bursa Efek Indonesia (BEI) Tahun 2004-2009, AAT Professional Journals.

Emirzon, J. 2006. Regulatory Driven dalam Implemtasi Prinsip-Prinsip Good Corpoaret Governance pada Perusahaan di Indonesia. Jurnal Manajemen \& Bisnis Sriwijaya. 4.

Fakhrudin \& Sophian. 2001. Perangkat dan Model Analisis Investasi di Pasar. Modal. Jakarta: Elex Media Komputindo. 
Gunarsih, T. 2010. Struktur Corporate Governance dan Ketepatan Waktu Penyampaian Laporan Keuangan: Perbandingan Model Logistic dan Neural Network. Jurnal Keuangan dan Perbankan. 4 (2).

Harjito, D. A \& Martono. 2005. Manajemen Keuangan. Yogyakarta: Ekonesia.

Haryanto, S. 2011. Karakteristik Perusahaan dan Risiko Bisnis Terhadap Harga Saham Pada Industri Otomotif di Bursa Efek Indonesia. Jurnal Ekonomi Modernisasi. 7(2).

Indriani, A \& Widyarti, E. T. 2013. Penentu-Penentu Struktur Modal Perusahaan yang Sahamnya Masuk Jakarta Islamic Index. Jurnal Dnamika Manajemen. 4 (1): 59-68.

Jandik, T \& Makhija, A.K. 2005. Debt, Debt Structure and Corporate Performance after Unsuccessful Takeover: Evidence from Targets that Remain Independent. Journal of Corporate Finance 11: 882-914.

Jensen, M. \& Meckling, W. 1976. Theory of the Firm: Managerial Behavior Agency Cost, and Ownership Structure. Journal of Finance Economics. 3: 305-360.

Jensen, C. M. 1986. Agency Costs of Free Cash Flow, Corporate Finance and Takeovers. American Economic Review. 76: 323-329.

Jensen, C. M. 2001. Value Maximization, Stakeholder Theory, and the Corporate Objective Function, 01-09: 1-21. Working Paper. Harvard Business School.

Kesuma, A. 2009. Analisis Faktor yang Mempengaruhi Struktur Modal serta Pengaruhnya Terhadap Harga Saham Perusahaan Real Estate yang Go Public di Bursa Efek Indonesia. Jurnal Manajemen dan Kewirausahaan. 11(1): 38-45.

Lin, K. L. 2006. Study on Related Party Transaction with Mainland China in Taiwan Enterprises. Unpublished Dissertation. China: Departemen Manajemen, Universitas Guo Li Cheng Gong.

Lukviarman, N. 2004. Ownership Structure and Firm Performance: The Case of Indonesia. Unpublished Thesis. Australia: Curtin University of Technology

Mahendra, D. A., Artini, L. G. S \& Suarjaya, A. A. G. 2012. Pengaruh Kinerja Keuangan terhadap Nilai Perusahaan pada Perusahaan Manufaktur di Bursa Efek Indonesia. Jurnal Manajemen, Strategi Bisnis, dan
Kewirausahaan. 6(2).

Meythi, M. R \& Debbianita. 2012. Pengaruh Struktur Modal terhadap Nilai Perusahaan dengan Pertumbuhan Perusahaan sebagai Variabel Moderating. Laporan Penelitian tidak dipublikasikan. Bandung: Universitas Maranatha.

Miller, M. H \& Modigliani, F. 1961. Dividend Policy under Asymetric Information. Journal of Finance. 411-433

Modigliani, F \& Miller, M. H. 1963. Corporate Income Taxes and Cost Of Capital. American Economic Review.

Pangemanan, S \& Mawikere, L. 2011. Pengaruh Ukuran Perusahaan dan Pertumbuhan Perusahaan Terhadap Earning PerShare Pada Industri Tekstil Di Bursa Efek Indonesia. Jurnal Riset Akuntansi dan Auditing Goodwill. $2(1)$.

Putra, T .P., Chabachib, M., Haryanto, M \& Pangestuti, I. R. D. 2010. Pengaruh Kinerja Keuangan dan Beta Saham terhadap Price to Book Value (Studi Pada Perusahaan Real Estate dan Property yang Listed di Bursa Efek Indonesia Periode Tahun 2004-2006). Jurnal-Tesis-Win. Universitas Diponegoro Semarang. Available at: http://www. win2pdf.com. Diunduh pada 02 Mei 2012.

Ratih, S. 2011. Pengaruh Good Corporate Governance Terhadap Nilai Perusahaan dengan Kinerja Keuangan sebagai Variabel Intervening Pada Perusahaan Peraih The Indonesia Most Trusted Company CGPI. Jurnal Kewirausahaan. 5 (2).

Ridloah, S. 2010. Faktor Penentu Struktur Modal: Studi Empirik pada Perusahaan Multifinansial. Jurnal Dinamika Manajemen. 1 (2): 144-153.

Rodoni, A. 2002. Penawaran Saham Perdana: Pengalaman di Bursa Efek Jakarta 1990-1998. Proceeding Simposium Nasional Keuangan In Memorium Prof. Bambang Riyanto. 214-241.

Sukasih, N. K \& Susilowati, A. S. 2011. Dampak Good Corporate Governance terhadap Kinerja Perusahaan (Study kasus di Bursa Eek Indonesia. Jurnal Bisnis dan Kewirausahaan. $7(3)$.

Soliha, E \& Taswan. 2002. Pengaruh Kebijakan Hutang terhadap Nilai Perusahan serta Beberapa Faktor yang Mempengaruhinya. Jurnal Bisnis dan Ekonomi. 
Sugeng Haryanto / Identifikasi Ekspektasi Investor melalui Kebijakan Struktur Modal ...

Sugihen, S. G. 2003. Pengaruh Struktur Modal terhadap Produktivitas Aktiva, Kinerja Keuangan, serta Nilai Perusahaan Industri Manufaktur Terbuka diIndonesia. Disertasi tidak dipublikasaikan. Surabaya: Universitas Airlangga

Sujoko \& Ugi, S. 2007. Pengaruh Struktur Kepemilikan Saham, Leverage Faktor Intern dan Faktor Ekstern terhadap Nilai Perusahaan. Jurnal Manajemen dan Kewirausahaan. 9 (1): 41-48.

Swa 27 XXIX 19 Desember 2013-8 Januari 2014. Indonesia Most Trusted Companies 2013.

Swa 27 XXVII 20 Desember 2012-9 Januari 2013. 10 Tahun Survei GCG Indonesia Most Trusted Companies 2012.

Tjager, I. N., Alijoyo, F. A., Djemat, H. R \& Soembodo, B. 2003. Corporate Governance. Jakarta: Prenhallindo.
Tumirin. 2007. Analisis Penerapan Good Corporate Governance dan Nilai Perusahaan. Jurnal BETA (Bisnis, Ekonomi dan Akuntansi). 6.

Wardani, D. K \& Hermuningsih, S. 2011. Pengaruh Struktur Kepemilikan terhadap Nilai Perusahaan dengan Kinerja Keuangan dan Kebijakan Hutang sebagai Variabel Intervening. Jurnal Siasat Bisnis. 15 (1).

Wardoyo \& Veronica, M. T. 2013. Pengaruh Good Corporate Governance, Corporate Social Responsibilty dan Kinerja Keuangan Terhadap Nilai Perusahaan. Jurnal Dinamika Manajemen. 4 (2): 132-149.

Weston, F. J \& Thomas, E. C. 1997. Manajemen Keuangan: Jilid 2. Jakarta: Binarupa Aksara. 